\section{Aquifer Characterization and Physiochemical Analysis of District Dera Ghazi Khan Punjab, Pakistan}

Rudarsko-geološko-naftni zbornik

(The Mining-Geology-Petroleum Engineering Bulletin) UDC: $556.3: 550.8$

DOI: 10.17794/rgn.2021.3.4

Original scientific paper

\author{
Waqas Shafiq'; Hadayat Ullah'²; Muhammad Zaheer ${ }^{2}$; Mubashir Mehmood ${ }^{3}$; \\ Umer Farooq'; M Jehangir Khan'; Saad Ahmed Mashwani ${ }^{2}$; Sami Ullah' \\ ${ }^{1}$ Institute of Geology, University of the Punjab Lahore, 54590 Pakistan \\ ${ }^{2}$ Department of Earth \& Environmental Sciences, Hazara University Mansehra, 21300 Khyber Pakhtunkhwa, Pakistan \\ ${ }^{3}$ Department of Geology, Abdul Wali Khan University Mardan, 23200, Khyber Pakhtunkhwa, Pakistan \\ ${ }^{4}$ Department of Earth Sciences, Quaid-e-Azam University Islamabad, 45320, Pakistan
}

\begin{abstract}
The study area is located in the arid section of Punjab province, Pakistan. The accessibility of freshwater is the main problem in this area. The area is mainly flat and alluvial deposits are present down to $800 \mathrm{~m}$. The groundwater is not fit for drinking because of its salinity. Hence, it is essential to mark the transition between fresh water and saltwater. Resistivity models were used to locate freshwater areas. The saltwater areas are between 10 and $30 \mathrm{~m}$ deep. Salt flats and clayrich deposits are visible on resistivity maps and were identified by low resistance values. After linking resistivity data and maps, it is determined that the south portion of the area has a freshwater aquifer, especially at a depth of $200 \mathrm{~m}$. At this depth, the quality of water is very good, regardless of its mild salinity in some areas. The margin between salty and freshwater is set to no degree. This is dependent upon the recharge and usage of an aquifer. Groundwater pollution poses a severe threat to the city's residents. Results from the physio-chemical analysis of the water samples confirm the presence of arsenic in excessive amounts in water samples and are outside the limits set by the WHO and NDWQS. Just two out of 10 samples are within the limits for safe drinking water. The results of this research are valued for groundwater management and the installation of tubular wells in freshwater areas for households and irrigation purposes.
\end{abstract}

\title{
Keywords:
}

alluvial deposits; salinity; aquifer; physio-chemical; heavy metals

\section{Introduction}

Water is the most significant entity for life. Various social activities such as farming, industry, and many others depend on water. In underdeveloped nations like Pakistan, water contamination is a major problem. The local population has little access to fresh and clean drinking water (Amin et al., 2017). The population growth not only increased the demand for pure water, but it also increased the input of industrial and domestic sewage in the waterways, which had a huge impact on the water system. Some sub-level industries play their part in creating jobs for the residents of the surrounding city. Fertilizers and pesticides are used to improve the fertility of the land, and to some extent, they are also liable for the pollution of the aquifer. The contamination of water has become a serious problem for the community as this is the root of many health issues. The WHO reports that $85 \%$ of Pakistanis do not have access to safe drinking water (Azizullah et al., 2011). The main reservoirs of

Corresponding author: Hadayat Ullah

hadayatkhan68@yahoo.com the nation are extremely affected by industrial waste, farming, and high natality, (Walsh, 2000).

Heavy metals, pesticides, harmful chemicals, and urban waste are all sources of the contamination of water. In Pakistan, the inadequate dumping of industrial waste has a major impact on groundwater (Qadir et al., 2008). Groundwater is the chief source of water for innumerable uses. Around one-third of people use the groundwater for their daily life (Zurbrugg, 2002). Drinking polluted water causes serious health issues, such as kidney stones, hepatitis, and stomach disorders. In Pakistan, 20 to 40 percent of all patients are hospitalized for consuming polluted water, and $33 \%$ of annual deaths are due to diseases contracted through contaminated water (Hutton, et al., 2007). The purpose of our research is to characterize freshwater zones, as well as establish hydrostratigraphy of the subsurface. The important part of this research was to bring out samples of water from the research area and carry out laboratory analyses to find out different physiochemical parameters of the water.

Dera Ghazi Khan is a significant district in southern Punjab. The area of southern Punjab is $13,740 \mathrm{~km}^{2}$, which is a thin strip of very dry land. There are steep 


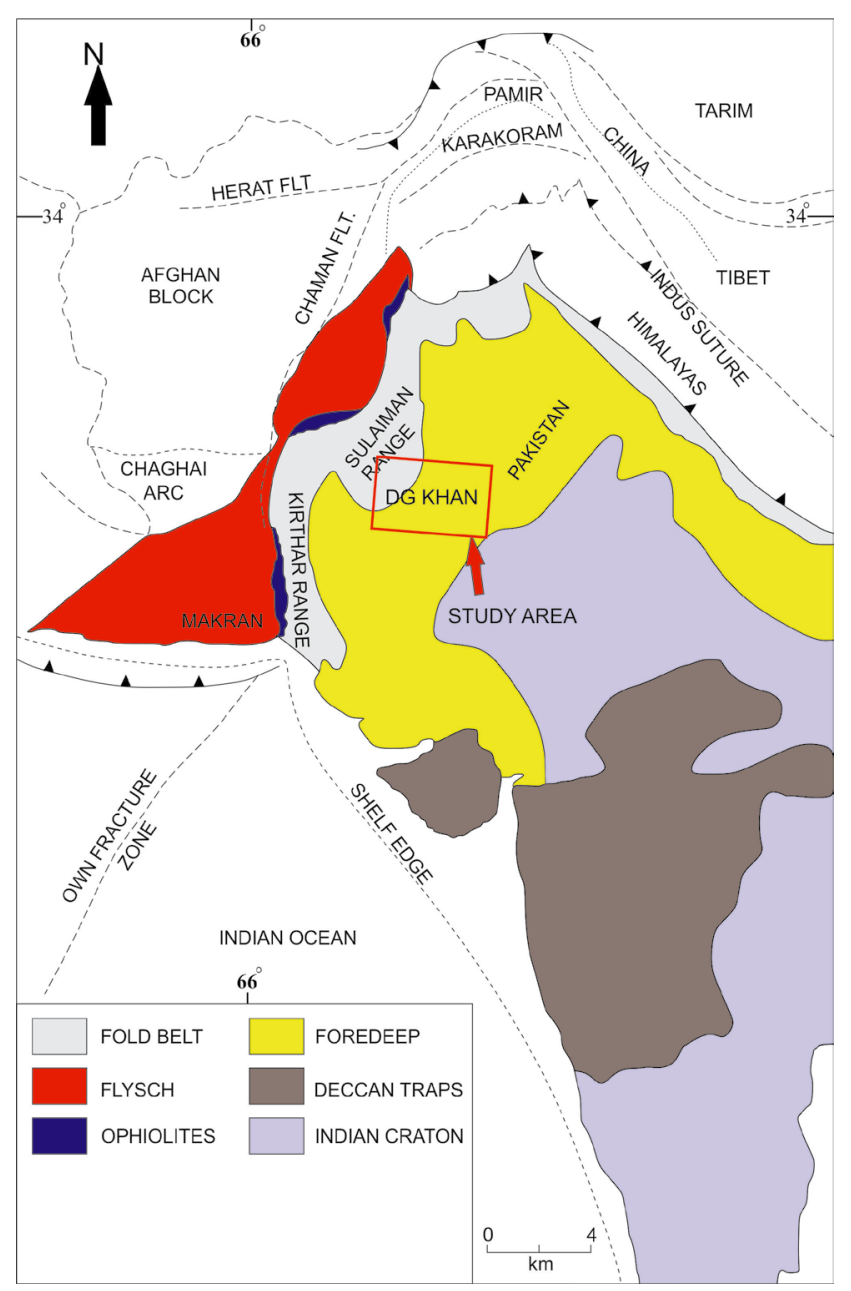

Figure 1: Geological Map of the study area

hills to the south of DG Khan and the rivers are often dry. In the rainy season, floods are originated from these steep hills. In summer, the temperature rises up to $50^{\circ} \mathrm{C}$. Geographically, Dera Ghazi Khan is significant because it connects the four provinces. The aquifer mainly consists of alluvial fans prograding into the study area. Sediments mainly consist of lacustrine silts interbedded by fluvial sands and gravels. The grain size of these filling sediments vary from very coarse alluvial fan gravels and river deposits with very high hydraulic conductivity to very fine lacustrine silt of very low hydraulic conductivity. Thus, the lithology and geomorphology of the sediments and deposition environment play a significant role in the development of clastic fluvial aquifers and their hydraulic properties, such as hydraulic conductivity and transmissivity (Bowling et al., 2005). The main goal of the research is to study diverse varieties of minerals in the water. After the data came from assessments, 2D models were created to meet the goals.

\section{Geology of the Study Area}

The research area is part of a tectonically active area of the Indian plate. The Indian plate is still converging

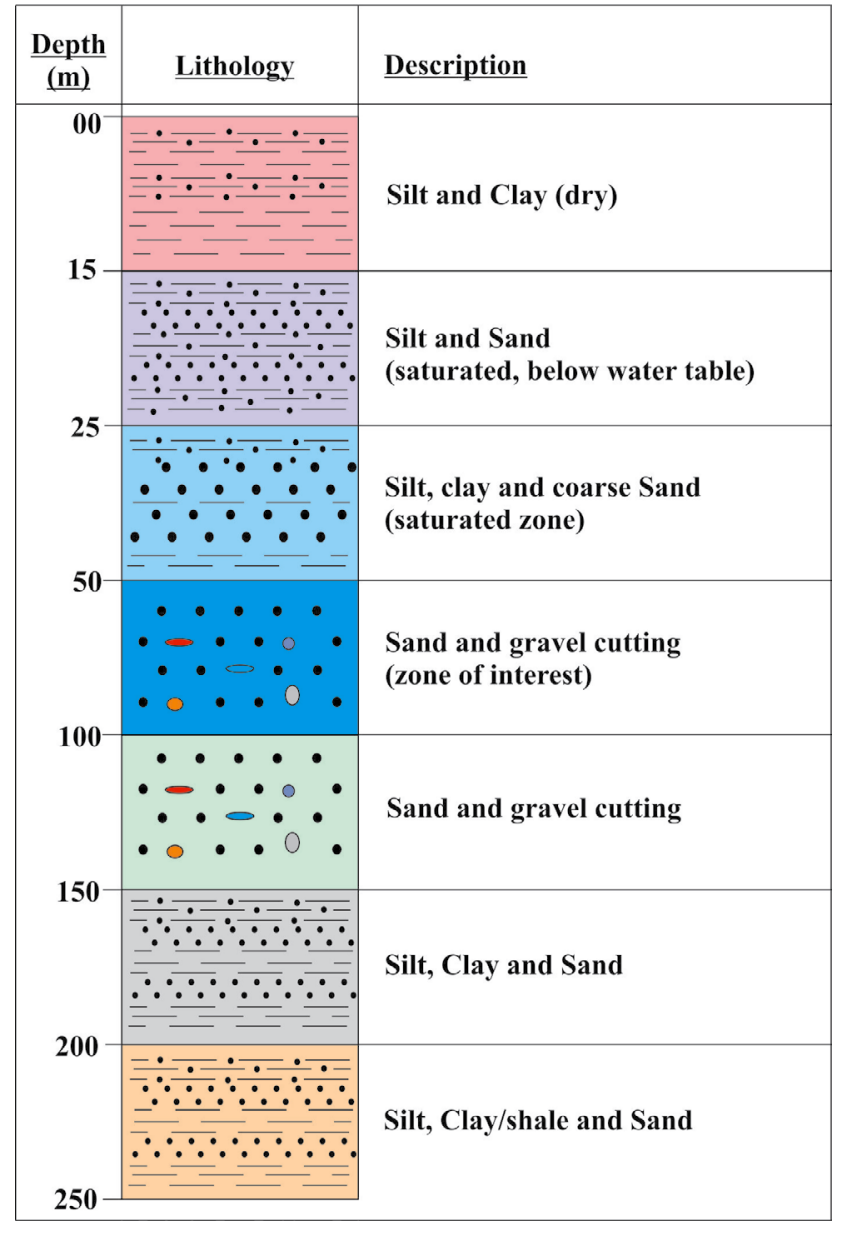

Figure 2: Schematic geological column of the subsurface in the study area

$36 \mathrm{~mm}$ per year beneath the Eurasian plate as a result of compression in the southwest part of the Himalayan Sulaiman fold, which formed a thrust belt in the middle Indus Basin. Along the east-west trending of the $\mathrm{Su}-$ laiman fold-and-thrust belt, tectonic activities occur (Asim et al., 2014). The length of this fold-and-thrust belt is up to $300 \mathrm{~km}$. The Sulaiman fold-and-thrust belt shows great compression and, due to this, it's quite narrow (see Figure 1). Tectonically, it is an active zone as the southern and eastern boundary of the Sulaiman belt is marked by Indus River deposits. The western margin of the belt is the suture zone that contains Ophiolites (Ahmad and Abbas, 1979).

Strata of Triassic to more recent age are found in the Sulaiman fold-and-thrust belt. Rock which is older than Triassic age is not exposed and not yet drilled. The youngest rocks which are found in the Sulaiman fold belt belong to the Siwaliks group. In the south and east edge of the belt, the Siwaliks group of recent age is present, whereas older rocks are located on the western side. Also, rocks of Permian age are present near Kalat (Asim et al., 2014). A significant unconformity is present between the Cambrian and Permian age. Boulders and sandstone show the condition of the basin in the Per- 


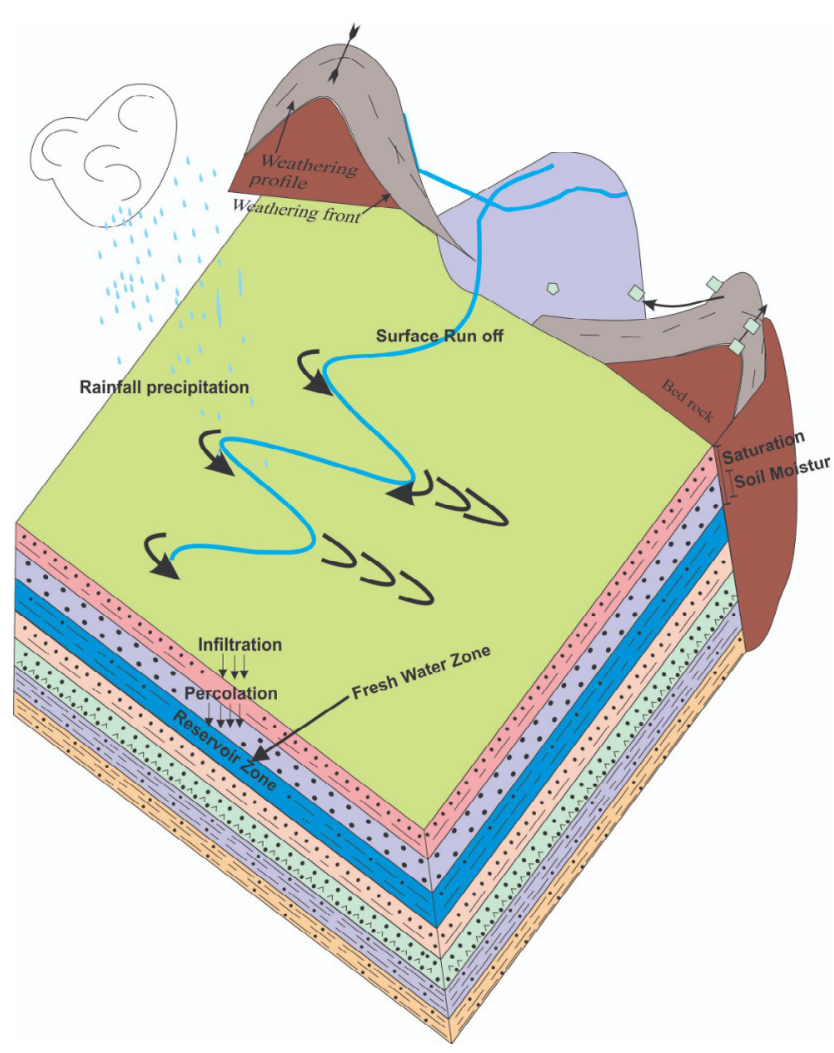

Figure 3: Hydrological conceptual model of the study area

mian age. Sandstone shows the gradual deposition by the stream and the boulder shows the rocks which were deposited and transported by the glaciers.

A schematic geological column of the subsurface lithology is shown in Figure 2. The column shows the lithology up to a depth of 250 meters.

To understand reservoir potential, the conceptual model of the research area is shown in Figure 3. It is considered a semi-confined aquifer and shows the freshwater zone in the study area. Generally, a semi-confined aquifer mainly contains sand, silt, and clay, having moderate to high aquifer hydraulic conductivity. The good water storage potential of the aquifer might depend on the frequency of rainfall and probable recharge conditions in that area.. The present conceptual model shows the freshwater zone in the study area.

\section{Material and Method}

An electrical resistivity survey was carried out in the field to create vertical resisitivity models (VES) in IPI2WIN software. Contour maps were created by Surfer software. The resistivity of various rocks and soils is diverse and depends upon porosity, grain size, permeability, shape, pore structure, orientation, and material compaction (Friedman, 2005). In the electrical resistivity technique, pore water plays a significant role. The data for research work was acquired with CG5 Terameter in district Dera Ghazi Khan between December 17th to 27 th. A total of 11 points were taken using the Schlumberger arrangement from 1.5 to 250 meters using half electrode spacing $(\mathrm{AB} / 2)$. The base map of the study area is shown in Figure 4. The specific resistance decreases with dissolved solids. The apparent resistivity of the subsurface is derived from the formula shown in Equation 1 (Varnavina et al., 2015).

$$
\rho a=K V / I
$$

where:

I = current,

$\mathrm{V}=$ voltage,

$\mathrm{K}=$ geometric factor whose value changes as electrode spacing are changes.

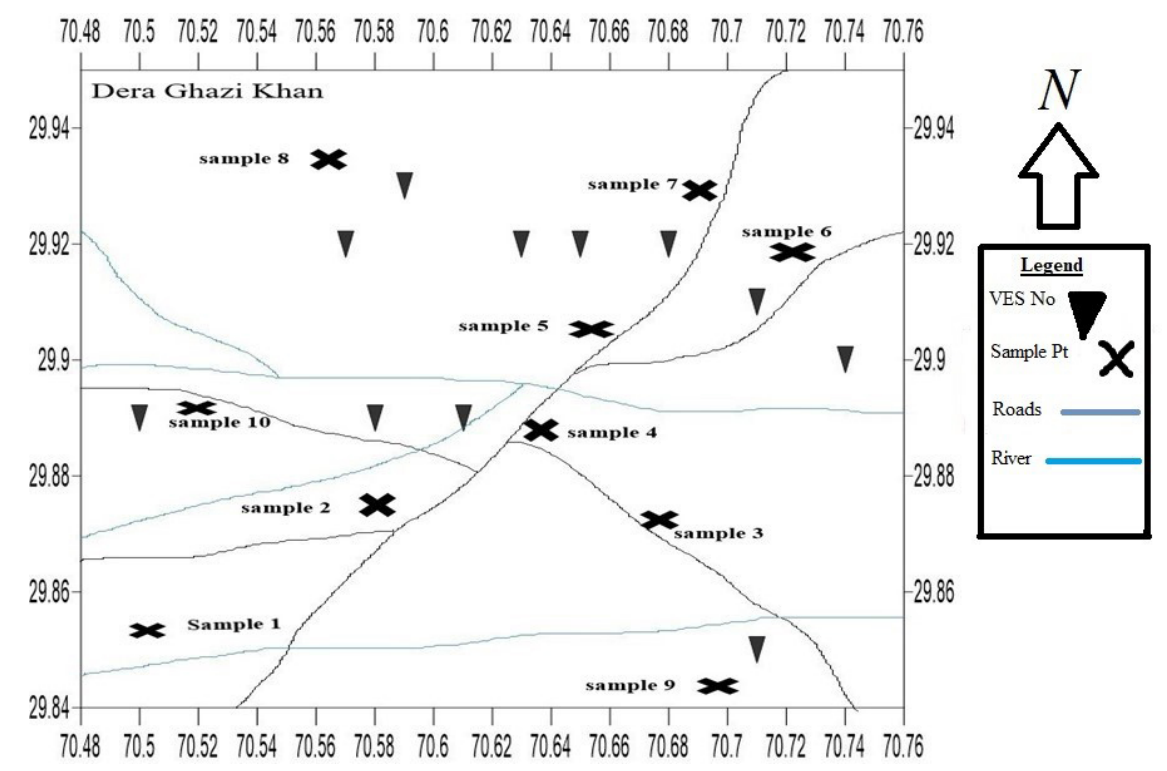

Figure 4: Base map of the study area showing ERS points, as well as water sample points collected from different places 


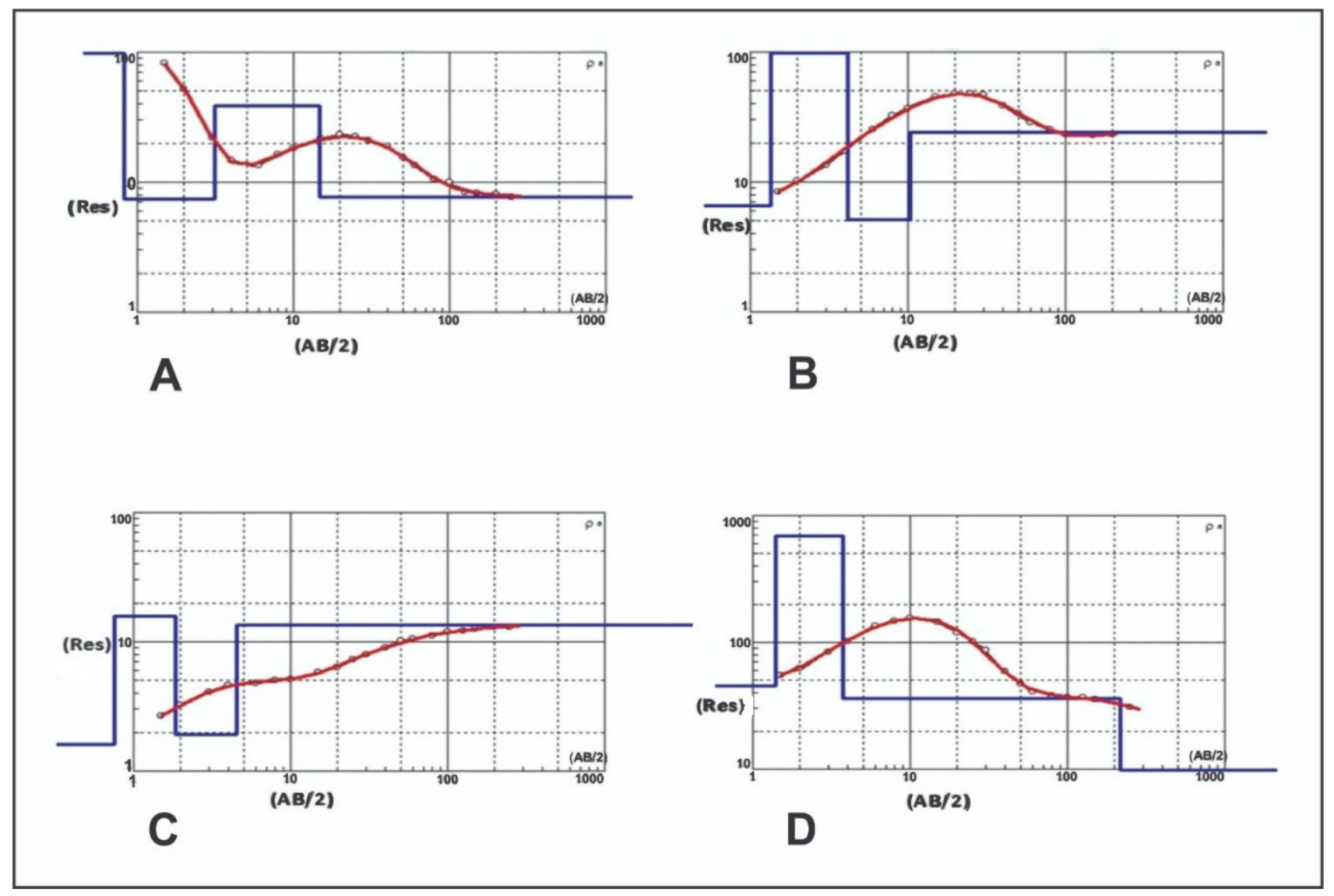

Figure 5: Apparent resistivity data are shown by circles:(A) Modelled resistivity for VES 1 (RMS=2.01\%) of the study area. (B) Modeled resistivity for VES 2 (RMS=1.92\%) of the study area. (C) Modeled resistivity for VES 3 (RMS=1.68\%) of the study area. (D) Modeled resistivity for VES 4 (RMS=1.14\%) of the study area.

\subsection{Electrical Resistivity Survey}

During the investigation of electrical resistivity, the electric current flows through the subsurface with two current electrodes. With the help of this method, we can classify areas of fresh and saltwater. This is extensively used in diverse groundwater and lithological settings where the salinity of the water varies (Mabrouk et al., 2019). This technique is based upon Ohm's law. The mathematical representation of Ohm's law shown in Equation 2 (Chernov et al., 1993):

$$
V=I \times R
$$

where:

$\mathrm{V}=$ potential difference (potential difference between the two electrodes),

I = current (electrical charge current through any crosssection), the unit of current is ampere (A),

$\mathrm{R}=$ resistance (the materials' ability to resist electric current motion).

The resistivity of a geological layer is linked to many electrical parameters and petrophysical properties like the physical and chemical features of the pore-fluid, the mineral alignment in the sediments, sediment porosity, permeability and the degree of saturation (Ginzburg and Levanon, 1976; Kazakis et al., 2016). Vertical electrical sounding (VES) is used for leveled and nearhorizontal margins. We used vertical electrical sounding for the geoelectrical model for subsurface layering to acquire the thickness of each layer beneath the subsurface (Muchingami et al., 2019).

\subsection{VES Modelling}

All the VES points are modeled with the IPI2WIN software (Zananiri et al., 2006). The apparent resistivity appears in small-scale circles. The black dark curve shows the apparent resistivity and the red colored curve represents an error between the apparent and bestmatched resistivity data. The lateral extension of the blue line represents the breadth of the layer (see Figure 5). The horizontal axis corresponds to the current electrode distance $(\mathrm{AB} / 2)$ in meters and the upright axis corresponds to the apparent specific resistance $(\mathrm{MN} / 2)$ in ohmmeters (Muhammad and Khalid, 2017).

\subsection{Resistivity data and Lithology Calibration}

The resistivity values tell us about the lithology that is present underground. The values of the same lithologies are dissimilar because of the water level. The conductiv- 
ity and resistance of the dissimilar rock types were shown in Table 1. Salt-water and freshwater resistivity are included also in this table.

\subsection{Physiochemical Analysis}

Different physio-chemical parameters of water were analysed, such as $\mathrm{pH}$, electric conductivity, total dissolved salts, sodium, potassium, chloride, arsenic and magnesium. The water samples collected in DG Khan were collected from many discrete locations across the city. A filter system was installed at the end of a landfill. Samples collected from these landfills affect the quality of the water below. Numbers were assigned to these collected samples from 1-10. Samples were collected in polyethylene (PE) bottles. Locations were defined by Geographic Positioning System (GPS) within latitude $30^{\circ}$ and longitude $72^{\circ}$ specified coordinates for Pakistan as shown in Table 2.

Table 1: Calibration among different lithologies and resistivities

\begin{tabular}{|c|c|c|}
\hline 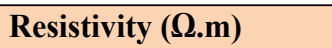 & Type of material & Remarks \\
\hline Resistivity less than 20 & Clay-silt & $\begin{array}{l}\text { Unsaturated } \\
\text { zone }\end{array}$ \\
\hline $\begin{array}{l}\text { Resistivity greater } \\
\text { than } 20\end{array}$ & Sand-Gravel & $\begin{array}{l}\text { Unsaturated } \\
\text { zone }\end{array}$ \\
\hline Resistivity less than 150 & Sand-Gravel & Saturated zone \\
\hline Resistivity less than 20 & Clay-silt & Saturated zone \\
\hline Resistivity less than 30 & Shales & Saturated zone \\
\hline Resistivity less than 10 & Saline sediments & Saturated zone \\
\hline
\end{tabular}

Table 2: Longitude, latitude, and locations of collected samples from DG Khan City

\begin{tabular}{|l|l|l|l|}
\hline Parameters & Latitude & Longitude & Location \\
\hline Sample \#1 & 30.05 & 70.65 & $\begin{array}{l}\text { Dumping site } \\
\text { filtration plant }\end{array}$ \\
\hline Sample \#2 & 30.05 & 70.65 & Dumping site mosque \\
\hline Sample \#3 & 30.03 & 70.67 & Shah wala khaki chok \\
\hline Sample \#4 & 30.01 & 70.68 & Basti khaki \\
\hline Sample \#5 & 30 & 70.7 & Samina road \\
\hline Sample \#6 & 30 & 70.72 & Bastikaheeri \\
\hline Sample \#7 & 30.01 & 70.75 & Chahdharkhanwala \\
\hline Sample \#8 & 30 & 70.66 & Kahri \\
\hline Sample \#9 & 29.97 & 70.68 & Paigah \\
\hline Sample \#10 & 29.97 & 70.52 & $\begin{array}{l}\text { Near DG Khan } \\
\text { Airport }\end{array}$ \\
\hline
\end{tabular}

\subsection{Laboratory Analysis}

The collected samples from the field were analyzed in a GSP (Geological Survey of Pakistan) laboratory. Physical parameters such as $\mathrm{pH}$, electric conductivity and total dissolved salts were determined with the help of an electro-chemical analyzer on the spot, while anions including $\mathrm{As}, \mathrm{Mg}, \mathrm{K}, \mathrm{Na}$ and chloride were determined using a spectrophotometer HACH (DR2800). The standard values for groundwater pollutants are illustrated in Table 3.

\section{Results and discussion}

Various resistivity models were prepared from the resistivity data of the study area to effectively obtain the targets of this research work. 2D models are generated and given below along with the interpretation of results. Figure 6A shows the resistivity graph at $10 \mathrm{~m}$ below the groundwater level. Clay and silt exist in the northern segment of the study area. According to the resistivity field data, there is silt and sand in the southward segment. The east and west are also covered by clay and sand. Therefore, we can estimate that clay, silt, sand, and gravel will appear at a depth of $10 \mathrm{~m}$. The $25 \mathrm{~m}$ resistivity model Figure 6B shows very small deviations compared to the $10 \mathrm{~m}$ resistivity model Figure 6A. On the north side of the model Figure 6B, there is a low specific resistivity and a horizon of saltwater is indicated. The southern and western side of the Figure 6B show a freshwater aquifer. In the northern zone of $50 \mathrm{~m}$ depth, there is a deep freshwater zone and the lithology consists of clay and silt. The northwest and southeast parts of the model show a small area of saltwater (see Figure 6C). The presence of freshwater aquifers in the area are shown in the south and west part of the model. On the north side of the map, a saltwater horizon is found. Silt and clay can be seen in the south of the model.

The resistivity graph at a depth of $100 \mathrm{~m}$ is shown in Figure 6D. The model indicates a freshwater aquifer is spread all over the map. Clay, silt, and sand are present at a $100 \mathrm{~m}$ depth according to resistivity data. For freshwater, $100 \mathrm{~m}$ depth is sufficient for a tube well (Chakraboti et al., 2008). Fewer smaller resistivity values were because of clays and silt. The extreme resistivity at $100 \mathrm{~m}$ depth was $68 \Omega \mathrm{m}$ because of the presence of clay and silt, and this denotes the best zone for an aquifer in the study area.

Resistivity models at levels of $150 \mathrm{~m}, 200 \mathrm{~m}$, and 250 $\mathrm{m}$ depth are displayed in Figures $6 \mathbf{E}, \mathbf{F}$, and $\mathbf{G}$. The largest value of a resistivity model of a depth of $150 \mathrm{~m}$

Table 3: Cut-off values of Groundwater Pollutants

\begin{tabular}{|l|l|l|l|l|l|l|l|l|}
\hline Standards & EC & PH & TDS & Na(mg/l) & K(mg/l) & $\mathbf{C l}(\mathbf{m g} / \mathbf{l})$ & $\mathbf{A s ( m g / l )}$ & $\mathbf{M g}(\mathbf{m g} / \mathbf{l})$ \\
\hline WHO(1993) & 1000 & $6.5-8.5$ & $<1000$ & $30-60$ & 5.2 & 250 & 0.01 & 30 \\
\hline NDWQS(2010) & 1000 & $6.5-8.5$ & $<1000$ & $30-60$ & 5.2 & 250 & $<0.05$ & 30 \\
\hline
\end{tabular}




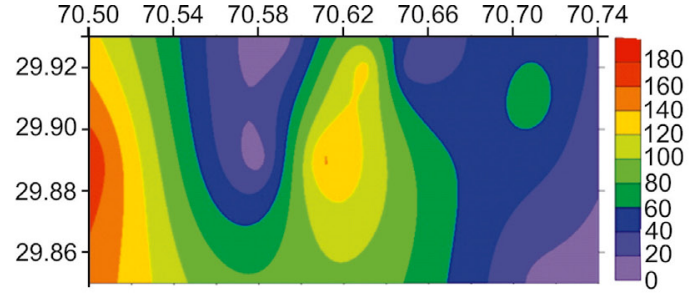

A

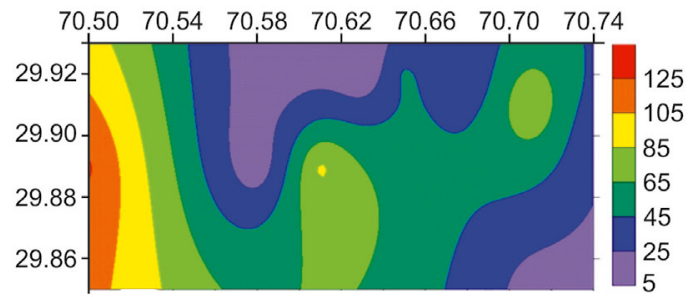

C

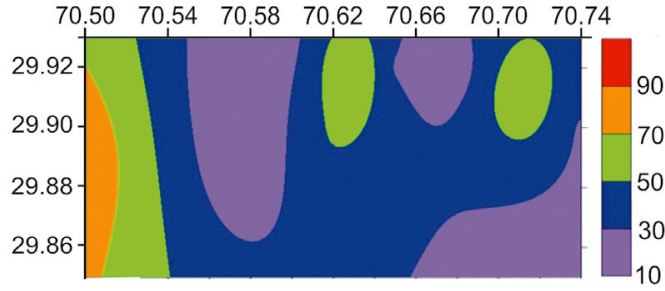

B

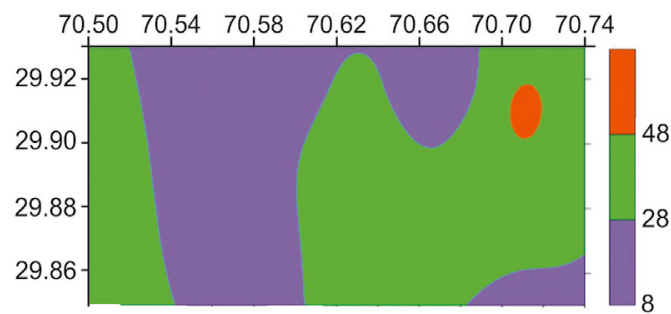

D

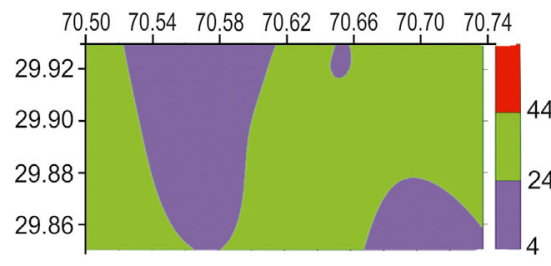

E

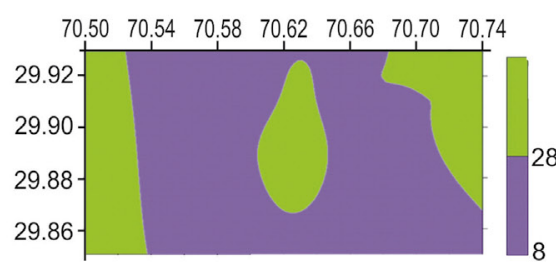

$\mathbf{F}$

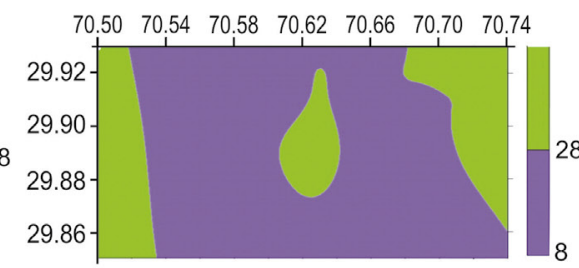

G

Figure 6: (A) Resistivity model at a $10 \mathrm{~m}$ depth of the study area. (B) Resistivity model at a $25 \mathrm{~m}$ depth of the study area. (C) Resistivity model at a $50 \mathrm{~m}$ depth of the study area. (D) Resistivity model at a $100 \mathrm{~m}$ depth of the study area. (E) Resistivity model at a $150 \mathrm{~m}$ depth of the study area. (F) Resistivity model at a $200 \mathrm{~m}$ depth of the study area. (G) Resistivity model at a $250 \mathrm{~m}$ depth of the study area.

was $44 \Omega . m$ (Figure 6E). Freshwater aquifers are shown on the north and south parts of the model. Towards the north and southeast of the model, the low resistivity layer indicates a saltwater area. Apart from that low resistivity area, the $150 \mathrm{~m}$ deep study area has freshwater aquifers. Figure 6F shows the resistivity model of the $200 \mathrm{~m}$ depth level. At a $200 \mathrm{~m}$ depth, approximately all of the study area has a fresh water zone. Due to less resistivity, we can expect that both clay and sandy dust will exist at this level. The small low resistivity horizon shows the saltwater zone. So, it has the potential to be the best freshwater aquifer. Figure 6G shows a resistivity model at $250 \mathrm{~m}$ for the saline and freshwater aquifer where $48 \Omega \mathrm{m}$ was the highest resistivity value at $250 \mathrm{~m}$ depth. The resistivity model indicates that there is a very great freshwater potential at a $250 \mathrm{~m}$ depth Figure 6G. Clays and sandy silt are existing as a lithology. A less resistive zone is present at a $250 \mathrm{~m}$ depth. With the comparison of resistivity at a depth of $200 \mathrm{~m}$, the resistance value is almost the same. It can be concluded here that at a depth of $200 \mathrm{~m}$, freshwater aquifers are more valuable than freshwater at a depth of $250 \mathrm{~m}$ because, at a depth of $200 \mathrm{~m}$, the salt surface is less than those at $250 \mathrm{~m}$.

The results of physico-chemical data from the 10 sites of DG Khan City, with maximum, minimum, mean values are shown in Table 5, and water sample results are shown in Table 6. The electrical conductivity (EC) values vary from $3100 \mu \mathrm{S} / \mathrm{cm}$ to $8000 \mu \mathrm{S} / \mathrm{cm}$ with an average of $6315 \mu \mathrm{S} / \mathrm{cm}$ from 10 samples. Figure 7a shows the results of EC, in which all the samples show higher values that represent high salinity in the soil. As per the WHO and the NDWQS, the quality of water used for drinking should be between $\mathrm{pH} 6.5$ and 8.5. The average $\mathrm{pH}$ value in our samples was 7.705 , which represents alkaline in nature. All the samples lie within the WHO range as can be seen in Figure 7b. The maximum TDS value for drinking water should not exceed $1000 \mathrm{mg} / 1$ (Al-Shaibani, 2008; Shahab et al. 2018). All the samples are above the safety limits for TDS (see Table 4). There is a direct relationship between EC and TDS, that is why TDS was calculated using the mathematical relation presented in Equation 3. Thirumalini and Joseph (2009) defined the relation as:

$$
\mathrm{TDS}=\mathrm{k}_{\mathrm{e}} \times \mathrm{EC}
$$

where;

$\mathrm{k}_{\mathrm{e}}-$ correlation factor whose value varies between 0.55 and 0.8 .

The environment of dissolved elements present in the water samples depends on the physical structure of the rocks as well as chemical configuration, along with the $\mathrm{pH}$ value in the vicinity of the aquifers (Sajil et al., 
Table 4: TDS (Total Dissolved Solids) value chart

\begin{tabular}{|l|l|}
\hline TDS Value & Remarks \\
\hline $0-300 \mathrm{mg} / \mathrm{L}$ & Excellent \\
\hline $300-500 \mathrm{mg} / \mathrm{L}$ & Good \\
\hline $500-700 \mathrm{mg} / \mathrm{L}$ & Fair \\
\hline $700-1000 \mathrm{mg} / \mathrm{L}$ & Moderate \\
\hline$>1000 \mathrm{mg} / \mathrm{L}$ & Undrinkable \\
\hline
\end{tabular}

2014; Zaheer et al., 2017). The TDS values from all 10 samples range from maximum to minimum i.e. 3050 $\mathrm{mg} / \mathrm{l}$ to $1200 \mathrm{mg} / \mathrm{l}$ respectively with an average of 2415 $\mathrm{mg} / \mathrm{l}$, which is not fit for potable water, but it can be used for irrigation purposes. Figure $7 \mathbf{c}$ shows the concentration of TDS in the graph.

The concentration of $\mathrm{Na}^{+}$ions varies between 440 to $830 \mathrm{mg} / \mathrm{l}$ while $\mathrm{Mg}^{+}$ions have concentration ranges be-

Table 5: Statistical summary of groundwater samples collected from DG Khan City

\begin{tabular}{|l|c|c|c|c|c|c|c|c|}
\hline & EC & TDS & pH & Na & K & Cl & Mg & As \\
\hline Max & 8000 & 3050 & 8.05 & 830 & 16.8 & 328.4 & 25 & 11.87 \\
\hline Min & 3100 & 1200 & 7 & 440 & 11.6 & 0.6 & 10 & 0.63 \\
\hline Mean & 6315 & 2415 & 7.705 & 675 & 14.58 & 50.31 & 17.4 & 3.584 \\
\hline
\end{tabular}

Table 6: Water sample results of DG Khan City

\begin{tabular}{|l|l|l|l|l|l|l|l|l|}
\hline Sample No. & $\mathbf{E C}(\boldsymbol{\mu S} / \mathbf{c m})$ & $\mathbf{T D S}(\mathbf{p p m})$ & $\mathbf{p H}$ & $\mathbf{N a}(\mathbf{m g} / \mathbf{l})$ & $\mathbf{K}(\mathbf{m g} / \mathbf{l})$ & $\mathbf{C l}(\mathbf{m g} / \mathbf{l})$ & $\mathbf{M g}(\mathbf{m g} / \mathbf{l})$ & $\mathbf{A s}(\mathbf{m g} / \mathbf{l})$ \\
\hline Sample \#1 & 7450 & 3000 & 8.3 & 830 & 16.2 & 22.2 & 10 & 11.87 \\
\hline Sample \#2 & 7600 & 3050 & 8.1 & 790 & 15.4 & 16.3 & 14 & 10.4 \\
\hline Sample \#3 & 7500 & 2770 & 8.05 & 810 & 16.2 & 328.4 & 25 & 2.8 \\
\hline Sample \#4 & 8000 & 3200 & 8.3 & 850 & 16.8 & 39.6 & 22 & 1.2 \\
\hline Sample \#5 & 5650 & 2100 & 7.2 & 540 & 12.9 & 46.2 & 11 & 1.54 \\
\hline Sample \#6 & 3100 & 1200 & 7.0 & 430 & 11.8 & 28.8 & 17 & 0.63 \\
\hline Sample \#7 & 7500 & 2880 & 7.8 & 780 & 15.8 & 5.2 & 23 & 3.4 \\
\hline Sample \#8 & 7800 & 2900 & 7.7 & 790 & 16.1 & 1.3 & 26 & 1.7 \\
\hline Sample \#9 & 5500 & 1800 & 7.5 & 490 & 12.8 & 0.6 & 10 & 1.2 \\
\hline Sample \#10 & 3050 & 1250 & 7.1 & 440 & 11.6 & 14.5 & 16 & 1.1 \\
\hline
\end{tabular}

(a)

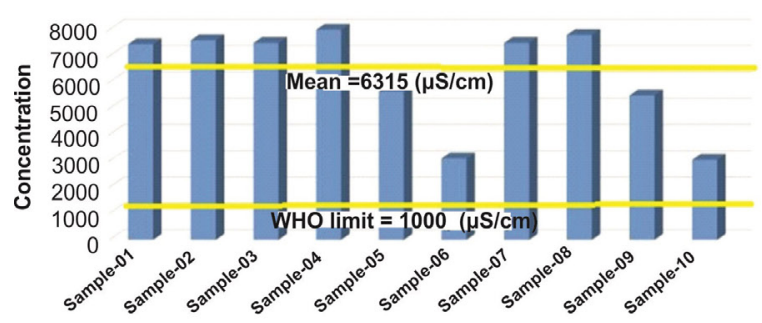

(c)

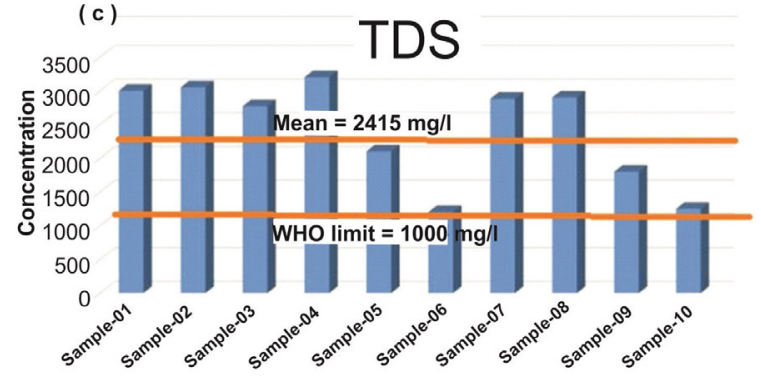

(b)

$\mathrm{PH}$

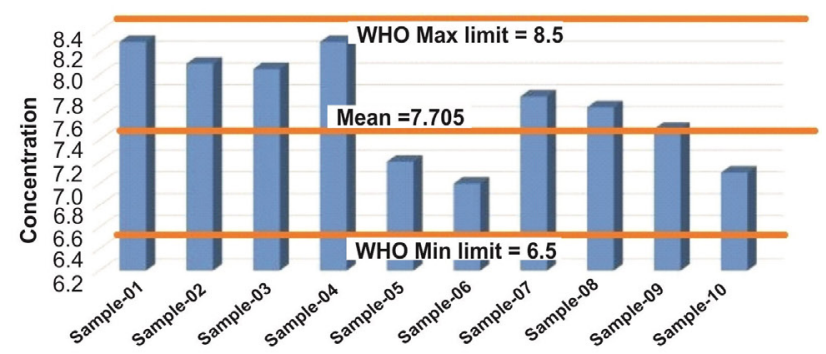

(d)

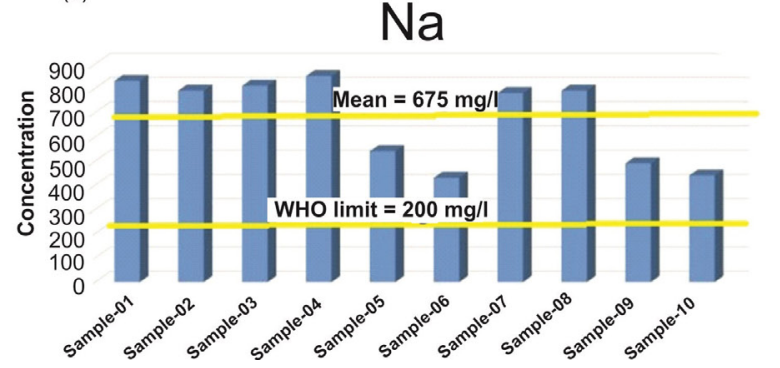

Figure 7: Graphical display of (a) EC (electrical conductivity) and (b) pH values within the study area. Mean, (c) TDS (total dissolved solids) and (d) Na (sodium) within the study area. Mean and WHO limits for these parameters are also shown. 
(a)

$\mathrm{Cl}$

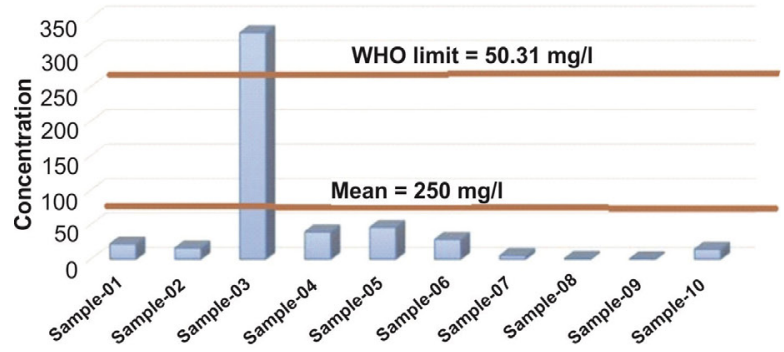

(c)

$\mathrm{k}$

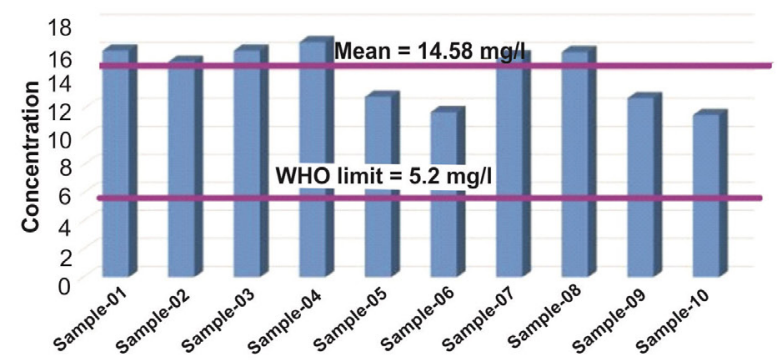

(b)

$\mathrm{Mg}$

WHO limit $=30 \mathrm{mg} /$
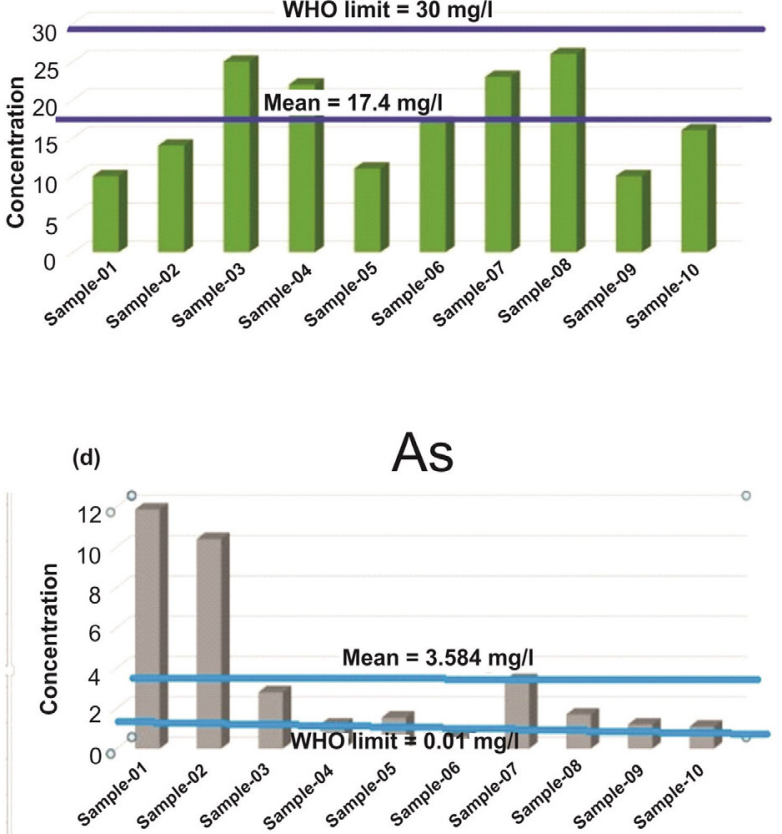

Figure 8: Graphical display of (a) $\mathrm{Cl}$ (chlorine) and (b) Mg (magnesium) within the study area. (c) $\mathrm{K}$ (potassium) and (d) As (arsenic) within the study area. Mean and WHO limits for these parameters are also shown.

tween 10 and $25 \mathrm{mg} / \mathrm{l}$. The average values for $\mathrm{Na}^{+}$and $\mathrm{Mg}^{+}$were very low, i.e. 675 and $17.4 \mathrm{mg} / 1$ respectively. All groundwater samples have a concentration of $\mathrm{Na}^{+}$ higher than the WHO limit, as shown in Figure 7d. The average $\mathrm{Na}^{+}$concentration in all samples is 675 , which is so high that it can cause many diseases such as chronic congestive, heart failure and ill effects, etc. On the other hand, $\mathrm{Mg}^{+}$ranges normally, i.e. 17.4 is the average range of $\mathrm{Mg}^{+}$, which is less than the WHO desirable standard, as shown in Figure $\mathbf{8 b}$.

The concentrations of $\mathrm{Cl}^{-}$ions are in the range between 0.6 to $328.4 \mathrm{mg} / \mathrm{l}$, with an average of $50.3 \mathrm{mg} / 1$ shown in Figure 5a. According to WHO standards, the allowable limit of $\mathrm{Cl}^{-}$is up to $250 \mathrm{mg} / \mathrm{l}$. Only one of the samples shows higher values from the desirable range. Other samples show a very low value of chlorine in the water. The potassium concentration in all samples ranges from 11.6 to $16.8 \mathrm{mg} / 1$, with an average of $14.58 \mathrm{mg} / \mathrm{l}$, as shown in Figure 8c. The recommended concentrations of $\mathrm{K}^{+}$in daily requirements are up to $3000 \mathrm{mg}$ (Edition, 2011). The standard WHO limit for $\mathrm{K}^{+}$is $5.2 \mathrm{mg} / \mathrm{l}$. All the samples lie above the WHO standard.

The analysis of drinking water is extremely important as it may indicate the origin of a serious illness. The tests

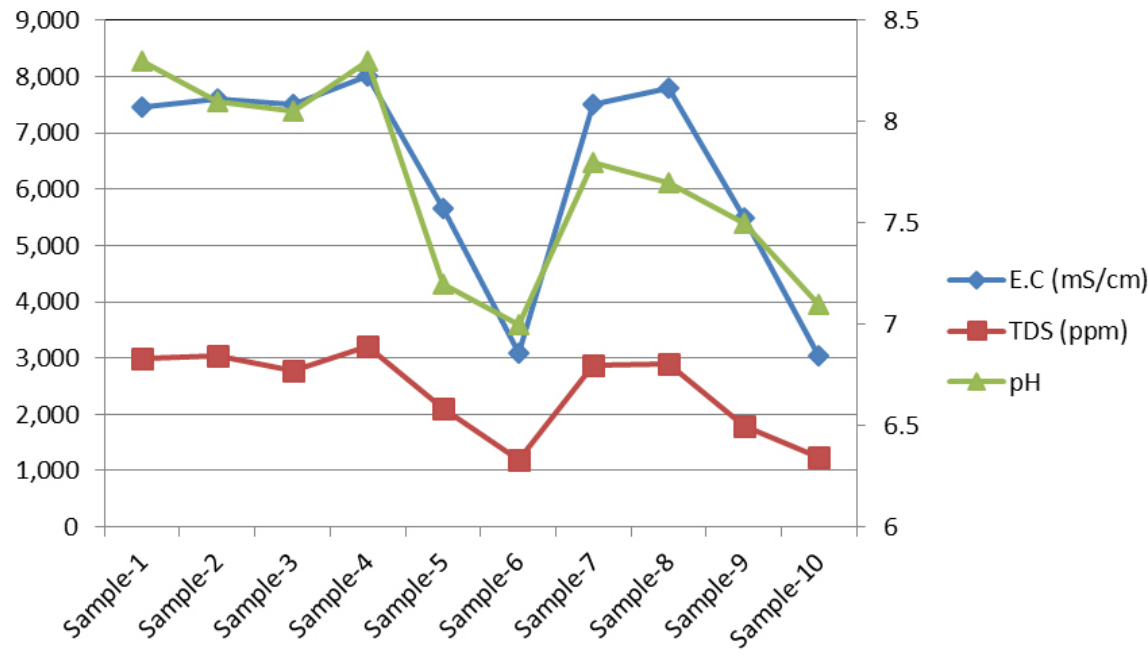

Figure 9: Cross-plot between EC, TDS, and PH 


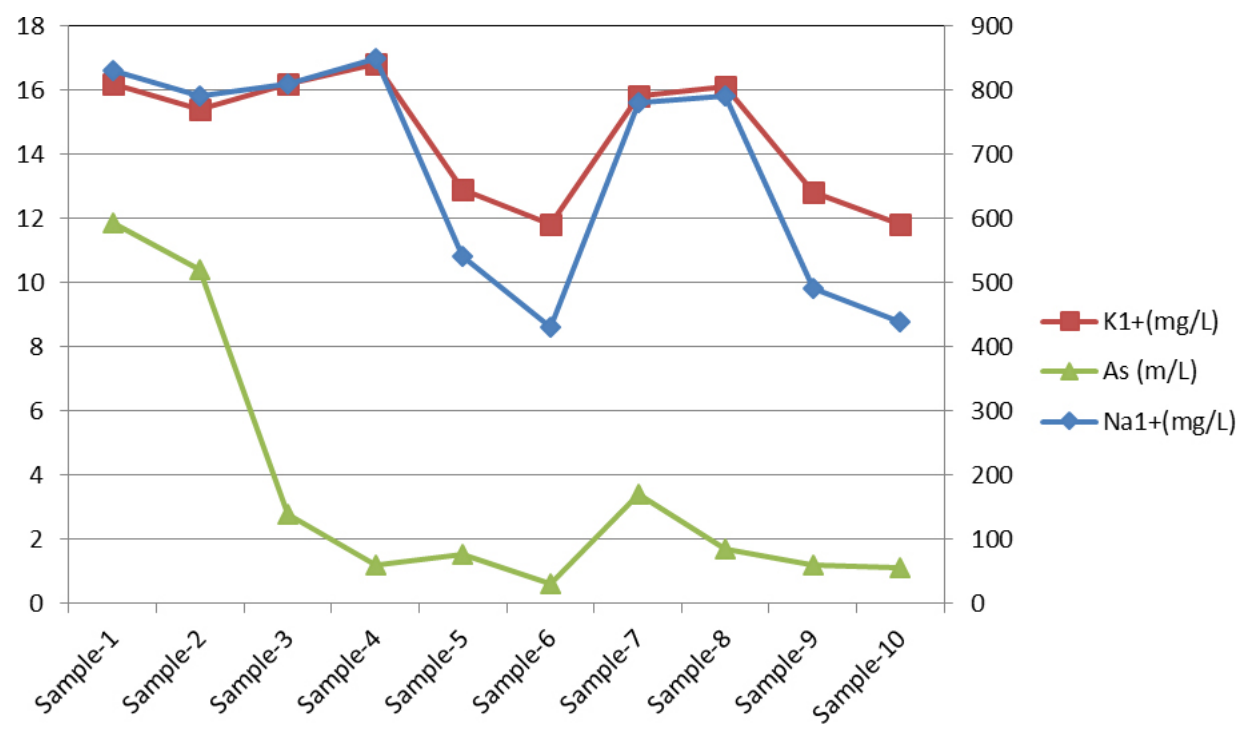

Figure 10: Cross-plot between $\mathrm{K}(\mathrm{mg} / \mathrm{L})$, As (mg/L) and $\mathrm{Na}(\mathrm{mg} / \mathrm{L})$

for arsenic (As) were only carried out with various heavy metals. Sample \#6 showed the lowest arsenic (As) with values of $0.63 \mathrm{mg} / \mathrm{l}$ and sample \#1 shows the maximum arsenic (As) value of $11.87 \mathrm{mg} / \mathrm{l}$. The mean value of all the collected samples is $3.54 \mathrm{mg} / \mathrm{l}$ ) and the range of values specified by international quality standards are not greater than $0.01 \mathrm{mg} / 1$. Figure $8 d$ shows the arsenic concentration in all samples.

\subsection{Graph comparison}

Out of all these samples, only sample \#6 and sample \#10 were recommended as drinking water, as the measured values of $\mathrm{pH}, \mathrm{TDS}$, and $\mathrm{EC}$ are within the limits of WHO and NDWQS. The cross-plot lies between EC $(\mu \mathrm{S} / \mathrm{cm})$, TDS $(\mathrm{ppm})$, and $\mathrm{pH}$, as shown in Figure 9.

This cross-plot tells the same scenario, just sample \#6 and \#10 fall within the WHO and NDWQS allowable limits. The second cross-plot is among $\mathrm{Na}(\mathrm{mg} / \mathrm{L}), \mathrm{K}$ $(\mathrm{mg} / \mathrm{L})$ and As $(\mathrm{mg} / \mathrm{L})$ (see Figure 10). The cross-plot illustrates the same situation, only samples \#6 and \#10 are within the acceptable limits of the WHO and NDWQS limits.

\section{Conclusion}

The groundwater perspective of the study area was concluded from the interpretation of the resistivity data. The main freshwater aquifers are on the north and east part of the study area. The eastern and western sections contain a freshwater aquifer, but it is in the region of a low resistivity area with saltwater. The resistivity models of the study area show the quality of the subsurface aquifer at different depths. The most probable depth for freshwater is $200 \mathrm{~m}$ throughout the region. Within a depth of $200 \mathrm{~m}$, the salt surface is very small, even at a depth of $250 \mathrm{~m}$, the salt surface is greater than at a depth of $200 \mathrm{~m}$.
After reviewing the results of analysis of the water samples, such as electrical conductivity (EC), TDS, $\mathrm{pH}$, and concentrations of heavy metals, it is concluded that the water quality in the entire region is well above the safety limits of the WHO and the NDWQS. The average arsenic concentration is $3.6 \mathrm{mg} / \mathrm{l}$ while it should not be higher than $0.01 \mathrm{mg} / 1$, according to the WHO limit values. The interpretations of the sample collected from the landfill are far too frightening as the arsenic concentration is around $11.87 \mathrm{mg} / \mathrm{l}$. Only 2 samples (sample \#6 and sample \#10) are somewhat within safe limits and meet potable quality standards. This is an alarming condition, as high-quality drinking water is not available in most parts of the city.

It is recommended that a groundwater survey must be carried out every five years under the observation of the Pakistan council of research in water resources to assess the quality of the groundwater. It is suggested that a vertical electrical probe should be used to increase the accuracy of the results. Saltwater dominates in areas up to $40 \mathrm{~m}$ deep, therefore it is advisable to drill wells to a depth of $50 \mathrm{~m}$ or more to the freshwater aquifer. The results of the water samples showed an alarming water quality situation for the entire area. The filter system installed at the landfill must be shut down immediately, as the arsenic concentration is alarming. The municipal government should establish a separate water data collection unit. Decision-makers should be allowed to make wise and courageous decisions to affect water quality.

\section{Acknowledgement}

This research did not receive any specific grant from funding agencies in the public, commercial, or not-forprofit sectors. Thank you, editor and anonymous reviewers, for your precious time to help us in the improvement of the manuscript. 


\section{References}

Al-Shaibani, A. M. (2008): Hydrogeology and hydrochemistry of a shallow alluvial aquifer, western Saudi Arabia. Hydrogeology journal, 16, 1, 155-165.

Ahmad, Z., and Abbas, S. G. (1979): The Muslim Bagh Ophiolites. Geodynamics of Pakistan. Geological Survey of Pakistan Quetta, 2, 243-249.

Amin, M. N., Kroeze, C., and Strokal, M. (2017): Human waste: An underestimated source of nutrient pollution in coastal seas of Bangladesh, India and Pakistan. Marine pollution bulletin, 118, 2, 131-140.

Asim, S., Khan, N., Qureshi, S. N., Hussain, F., and Bablani, S. A. (2014): Study of a Stratigraphic Trap of Paleocene/ Late Cretaceous Age with the Help of Seismic Data in Suleman Foredeep and Kirthar Foredeep Area Central and Southern Indus Basin, Pakistan. International Journal of Geosciences, 5, 10, 1049-1061.

Azizullah, A., Khattak, M. N. K., Richter, P., and Häder, D. P. (2011): Water pollution in Pakistan and its impact on public health a review. Environment international, 37, 2, 479-497.

Bowling, A. (2005): Mode of questionnaire administration can have serious effects on data quality. Journal of public health, 27, 3, 281-291.

Chakraborti, D., Singh, E. J., Das, B., Shah, B. A., Hossain, M. A., Nayak, B., and Singh, N. R. (2008): Groundwater arsenic contamination in Manipur, one of the seven NorthEastern hill states of India: a future danger. Environmental Geology, 56, 2, 381-390.

Chernov, N. I., Eyink, G. L., Lebowitz, J. L., and Sinai, Y. G. (1993): Derivation of Ohm's law in a deterministic mechanical model. Physical review letters, 70, 15, 2209-2212.

Edition, F. (2011): Guidelines for drinking-water quality. WHO chronicle, 38, 4, 104-108.

Friedman, S. P. (2005): Soil properties influencing apparent electrical conductivity: a review. Computers and electronics in agriculture, 46, 1-3, 45-70.

Ginzburg, A., and Levanon, A. (1977): Direct current resistivity measurements in archaeology. Geoexploration, 15, 1, 47-56.

Hutton, G., Haller, L., and Bartram, J. (2007): Global costbenefit analysis of water supply and sanitation interventions. Journal of water and health, 5, 4, 481-502.

Kazakis, N., Vargemezis, G., and Voudouris, K. S. (2016): Estimation of hydraulic parameters in a complex porous aquifer system using geoelectrical methods. Science of the Total Environment, 550, 742-750.
Mabrouk, M., Jonoski, A., Oude Essink, G. H., and Uhlenbrook, S. (2019): Assessing the Fresh-Saline Groundwater Distribution in the Nile Delta Aquifer Using a 3D Variable-Density Groundwater Flow Model Water, 11, 9, 1946-1953.

Muhammad, S., and Khalid, P. (2017): Hydrogeophysical investigations for assessing the groundwater potential in part of the Peshawar basin, Pakistan. Environmental Earth Sciences, 76, 14, 1-12.

Muchingami, I., Chuma, C., Gumbo, M., Hlatywayo, D., and Mashingaidze, R. (2019): Approaches to groundwater exploration and resource evaluation in the crystalline basement aquifers of Zimbabwe. Hydrogeology Journal, 27, 3, 915-928.

Qadir, A., Malik, R. N., and Husain, S. Z. (2008): Spatio-temporal variations in water quality of NullahAik-tributary of the river Chenab, Pakistan. Environmental monitoring and assessment, 140, 1-3, 43-59.

Sajil, K. P. J., Jegathambal, P., and James, E. J. (2014): Factors influencing the high fluoride concentration in ground water of Vellore district, South India. Environmental Earth Sciences, 72, 7, 2437-2446.

Shahab, A., Qi, S., Zaheer, M., Rashid, A., Talib, M. A., and Ashraf, U. (2018): Hydro-chemical characteristic and water quality assessment for drinking and agricultural purposes in District Jacobabad, Lower Indus Plain, Pakistan. International Journal of Agri-cultural and Biological Engineering, 11, 2, 115-121.

Varnavina, A. V., Khamzin, A. K., Torgashov, E. V., Sneed, L. H., Goodwin, B. T., and Anderson, N. L. (2015): Data acquisition and processing parameters for concrete bridge deck condition assessment using ground-coupled ground penetrating radar: Some considerations. Journal of Applied Geophysics, 114, 123-133.

Walsh, C. J. (2000): Urban impacts on the ecology of receiving waters: a framework for assessment, conservation and restoration. Hydrobiologia, 431, 2, 107-114.

Zaheer, M., Wen, Z., Zhan, H., Chen, X. and Jin, M. (2017): An experimental study on solute transport in one-dimensional clay soil columns. Geofluids, 4, 17, 1-17.

Zananiri, I., Memou, T., and Lachanas, G. (2006): Vertical electrical sounding (VES) survey at the central part of Kos Island, Aegean, Greece. Geosciences, 15, 4, 411-413.

Zurbrugg, C. (2002): Urban solid waste management in lowincome countries of Asia: How to cope with the garbage crisis. Presented for: Scientific Committee on Problems of the Environment (SCOPE) Urban Solid Waste Management Review Session. Durban South Africa, 11, 2, 1-13. 


\section{SAŽETAK}

\section{Karakterizacija vodonosnika i fizičko-kemijska analiza područja Dera Ghazi Khan, Punjab, Pakistan}

Istraživano područje smješteno je u pustinjskome dijelu provincije Punjab u Pakistanu, obilježenome nedostatkom pitke vode. Područje je najvećim dijelom zaravnjeno i prekriveno aluvijem koji mjestimice može dosegnuti i $800 \mathrm{~m}$ debljine. Podzemna voda nije pogodna za piće zbog slanosti. Stoga je iznimno važno prepoznati prijelaznu zonu između slatke i slane vode. Za lociranje slatkovodnih područja korišteni su modeli otpornosti. Područja slane vode duboka su između 10 i $30 \mathrm{~m}$. Taložine soli i gline opažaju se na kartama otpornosti niskim vrijednostima otpora. Uočeno je kako se na jugu područja javljaju vodonosnici slatke vode, čak na dubini od $200 \mathrm{~m}$, s vrlo dobrom kvalitetom vode, uz rijetku pojavu bočatosti. Granicu između slatke i slane vode nije moguće jednoznačno odrediti, a ovisi o dotoku i uporabi vodonosnika. Njihovo zagađenje može biti ozbiljan problem, poglavito za gradska područja. Rezultati fizičko-kemijske analize pokazali su nazočnost prevelikih količina arsena, tj. u granicama iznad dopuštenih klasifikacijama WHO-a i NDWQS-a. Od 10 samo su 2 uzorka bila u granicama koje određuju pitku vodu. Rezultati su vrijedan doprinos za gospodarenje tom podzemnom vodom te projektiranje bušotina kojima bi se pitka/slatka voda dovodila kućanstvima ili koristila za navodnjavanje.

\section{Ključne riječi:}

aluvij, slanost, vodonosnik, fizičko-kemijska svojstva, teški metali

\section{Author's contribution}

Waqas Shafiq (M.Phil Geology) participated in a resistivity survey of the study area and collected all the data. Hadayat Ullah (M.Phil. in Geology and Lecturer at Department of Geology Hazara University, Mansehra), Mubashir Mehmood (Ph.D Geology in progress) prepared the idea, completed the literature review, participated in all work stages and tested its correctness; Muhammad Zaheer (Ph. D in hydrology and water resources and Assistant Professor at Geology Hazara University Mansehra Pakistan) participated in proofreading and the final preparation of this manuscript. M Jehangir Khan (M.Phil. in Geology); Sami Ullah (M.Phil. in Geology); Umer Farooq (M.Phil. in Geology); and Saad Ahmed Mashwani (M.Phil. in Geology) participated in resistivity modeling, parameter estimations and their consistency. 